\title{
A Literature Review on the Factors Influencing R \& D Investment
}

\author{
Liujun Liu \\ Management School, Jinan University, Guangzhou, China \\ Email: lijun_liu601@163.com
}

How to cite this paper: Liu, L. J. (2017). A Literature Review on the Factors Influencing R \& D Investment. Chinese Studies, 6, 24-28.

https://doi.org/10.4236/chnstd.2017.61003

Received: January 24, 2017

Accepted: February 17, 2017

Published: February 21, 2017

Copyright $\odot 2017$ by author and Scientific Research Publishing Inc. This work is licensed under the Creative Commons Attribution International License (CC BY 4.0)

http://creativecommons.org/licenses/by/4.0/

\begin{abstract}
The development of enterprises is an important driving force for sustainable development, which is affected by many factors. In recent years, Chinese scholars put research on the influence factors of the problems of enterprise development mainly from corporate governance mechanism, human resources, financial condition and other internal factors and other factors outside the enterprise, i.e. fiscal policy, financial support. This article reviews and summarizes the relevant research literature from two perspectives of the internal factors and external factors.
\end{abstract}

\section{Keywords}

R \& D Investment, Internal Factors, External Factors

\section{Introduction}

In general, $\mathrm{R} \& \mathrm{D}$ activities of the enterprise are a kind of systematic activity which refers to the improvement of technology, products and services, and the transformation of scientific research results into reliable, cost-effective and innovative products, materials, equipment, processes and services. The $\mathrm{R} \& \mathrm{D}$ activities of enterprises are not only the main way to obtain the core technology, but also the foundation of the survival and development. Since in 2006, the Central Committee of the Communist Party of China put forward the goal of building an innovative country in 2020, the impact factors of R \& D investment have been a hot topic in Chinese academic circles. This paper intends to sort out the relevant research results about the factors influencing the $\mathrm{R} \& \mathrm{D}$ investment in enterprises in recent years, and puts forward some ideas and suggestions for further research in the future. The innovation of this research lies in a comprehensive review of the influencing factors of Chinese enterprises' $R$ \& D investment. This article will firstly review the internal factors that affect $R \& D$ invest- 
ment, which includes corporate governance mechanisms, human resources, financial conditions and other internal factors; then the external influence factors, that is fiscal policy and financial support, are reviewed; at the end of the article, we make a summary of the reviews and put forward some recommendations.

\section{The Internal Factors Affecting the R \&D Investment}

In the study of the impact of $\mathrm{R} \& \mathrm{D}$ investment from the company itself, the relevant literature mainly examines the impact of corporate governance mechanisms, human resources, financial conditions and other internal factors on R \& D investment.

\subsection{Corporate Governance}

On the impact of corporate governance mechanism on corporate R \& D investment, many domestic scholars have studied from the perspective of the size of the board of directors, executive incentive mechanism, ownership concentration and equity. Evidence from China Gem enterprise data shows that the number of board members and the proportion of executive stock ownership can promote the research and development strength (Liu Xiaoyuan \& Li Yongzhuang, 2012). By using the world bank survey data on China's manufacturing enterprises in 1483, Li Chuntao studied the effect of executive compensation incentive on R \& $\mathrm{D}$ investment under different ownership structure, which found that the state-owned enterprise is higher than the private enterprise in the R \& D intensity, and the manager's salary incentive can promote the innovation of the enterprise (Li Chuntao \& Song Min, 2010). Furthermore, research on Chinese Listed Companies demonstrate that high tech listed companies implementing executive stock incentive are tending to promote their R \& D investment (Tang Qingquan \& Xie Weimin, 2013), but there is no significant positive correlation between institutional ownership and $\mathrm{R} \& \mathrm{D}$ investment, and the impact of different institutional investors on R \& D investment is different (Li Yingzhao \& Wu Jihui, 2013). Wen Fang studied R \& D data from China listed companies, and found that the incentive effects of equity type on listed company R \& D investment intensity ranked from strong to weak: private property holdings, holdings of state-owned enterprises directly under the central government, the local state-owned holding enterprises, state-owned assets management institutions holding (Wen Fang, 2008). In addition, evidence from listed manufacturing and IT industry companies shows that the R \& D intensity of state controlled listed companies is significantly lower than that of non-state-owned listed companies.

\subsection{Human Resources}

From the perspective of human resources, top management team has become the main research subject. In view of Luo Zhengying (Luo Zhengying, Tang Lingling, \& Chang E, 2013), the average age of the top management team has no significant impact on $\mathrm{R} \& \mathrm{D}$ investment, but their average tenure is negatively correlated with corporate $\mathrm{R} \& \mathrm{D}$, and the proportion of the team members with 
technical background and corporate R \& D investment was positively correlated. Besides, the number of $\mathrm{R} \& \mathrm{D}$ personnel and $\mathrm{R} \& \mathrm{D}$ investment is positively related and the number of $\mathrm{R} \& \mathrm{D}$ personnel changes in $\mathrm{R} \& \mathrm{D}$ investment is significantly positive correlation.

\subsection{Financial Situation}

Another main focus of the research on the factors influencing the $\mathrm{R} \& \mathrm{D}$ investment is the financial situation of the enterprise. Insight from China small board listed companies demonstrates that the more redundant financial resources the company possesses the harder it will promote R \& D investment. On the other hand, strict corporate financial control may hinder company's $R$ \& D investment, corporate debt ratio is negatively correlated with $\mathrm{R} \& \mathrm{D}$ investment, corporate profits have significant positive correlation with $R \& D$ intensity of private enterprises and foreign-funded enterprises, but the state-owned enterprises are not significant (Cheng Liwei \& Dai Xiaoyong, 2012).

\subsection{Other Internal Factors}

In fact, the size of the enterprise also directly affects the ability of research and development, and affects the R\&D input. According to Jiang Tao's research, there is a positive correlation between R \& D investment and firm size (Jiang Tao, 2013). Besides, based on data from 1465 A -stock companies from 2010-2013, Jiang Nanchun's study shows that earnings per share have significant positive correlation with $\mathrm{R} \& \mathrm{D}$ intensity while asset liability ratio has significant negative correlation with R \& D intensity (Jiang Nanchun, 2015).

\section{The External Factors Affecting the R \& D Investment}

In the aspect of external factors, the paper mainly studies the influence of fiscal policy and financial support on R \& D investment.

\subsection{Fiscal Policy}

Research on Yangtze River Delta 77 listed high-tech enterprises about the incentive effect of current income tax preferential policies on $\mathrm{R} \& \mathrm{D}$ investment shows that income tax preferential policies have a positive role in promoting $\mathrm{R} \& \mathrm{D}$ investment, and the long-term effect of this promotion is stronger than the short-term effect (Zhao Yuehong \& Xu Min, 2013). Similarly, evidence from 67 small board company demonstrates that tax incentives and government subsidies have contributed to R \& D investment, and from World Bank data for 2003 it is found that the tax relief policy has significantly promoted the domestic enterprises to increase $\mathrm{R} \& \mathrm{D}$ investment. There's also research using samples from Chinese Listed Companies shows that with the change of the income tax rate, the tax burden of the company has a significant negative correlation with the intensity of research and development. Research on government R \& D subsidies shows that there's a negative relationship between government subsidies and $\mathrm{R}$ \& D investment. Base on Gem high-tech enterprises, it is found that the gov- 
ernment subsidies and R \& D investment of high-tech enterprises are significantly negatively correlated, and only exist in the enterprises with political connections. There's also similar conclusion derive from Shenzhen SME Board Listed Companies at year 2008. However, some studies have found the opposite conclusion that government subsidies are positively correlated with R \& D investment. Evidence from 2003-2005 China listed companies demonstrates that Government R \& D subsidies significantly promote enterprise technology innovation.

\subsection{Financial Support}

Research on the influence of financial support on R \& D investment, it's found that the effect of capital market debt financing on the $\mathrm{R} \& \mathrm{D}$ investment of high-tech listed companies is not obvious, while equity financing is positively correlated with the $\mathrm{R} \& \mathrm{D}$ investment of high-tech listed companies. The reform of the banking market and regional financial development actively promote the $R \& D$ investment development of China's listed companies. Besides, the positive impact of financial development on R \& D investment is obvious for small scale enterprises and private companies. More importantly, the development of domestic finance, which is measured by bank credit, stock market and corporate bond market, has greatly promoted the development of the whole industry.

\section{Conclusion}

Overall, in the existing literature, the researchers based on different angles studied the influence factors of corporate R \& D investment by empirical analysis, which leads new factors to continue to increase, different degree of innovation on the starting point, and continuous improvement of the research system. The conclusions and suggestions for the government and enterprises also have some guidance and reference significance.

Nevertheless, there are also some notable problems. Firstly, the relevant literatures are mostly based on the listed companies, and the discussion of unlisted private enterprises is less. In fact, because of small scale, weak research and less social supervision, there is a big difference between non-listed private enterprises and listed companies in R \& D investment decision and behavior. Besides, to enhance the ability of independent innovation of small and medium sized non-listed enterprises is the key link to realize the transformation of the mode of economic growth in China and to build an innovative country. Then to strengthen the study on the non-listed private enterprise of $\mathrm{R} \& \mathrm{D}$ investment factors is necessary. Secondly, in the study of individual factors, although with basically the same samples, data and methods, it leads to different conclusions. It is of great significance to strengthen the research on the transmission mechanism to increase the study efficiency. Last but not least, the present research on the influence of government policy on enterprise R \& D investment mainly focuses on tax incentives and Government R \& D subsidies; however, the policy of intellectual property rights and human resources policy also have an important impact 
on $\mathrm{R} \& \mathrm{D}$ investment. I recommend that the future study of government policy should include intellectual property policy and human resource policy.

\section{Acknowledgements}

The authors would like to thank the guest editors and the anonymous reviewers for their constructive comments and developmental suggestions throughout the revision process. I would also like to thank Iris, Flora for invaluable comments and suggestions on previous versions of this manuscript. All remaining errors are my own.

\section{References}

Cheng Liwei, \& Dai Xiaoyong. 成力为, 戴小勇. (2012). Analysis of the Distribution Characteristics of R \& D Investment and the Influencing Factors of R \& D Investment Intensity Based on Panel Data of 300 Thousand Industrial Enterprises in China 研发 投入分布特征与研发投资强度影响因素的分析一基于我国 30 万个工业企业面板数 据. Chinese Journal of Soft Science, 8 .

Jiang Tao. 蒋涛. (2013). Research on the Internal Factors of Enterprise R \& D Investment 企业研发投入内部影响因素研究. Shopping Mall Modernization, 7, 120.

JiangNanchun. 江南春. (2015). An Empirical Study on the Factors That Affect the Strength of R \& D Investment of Listed Companies Based on Endogeneity 基于内生性 的上市公司研发投入强度影响因素实证研究. Business Economics Research, 30, 108110.

Li Chuntao, \& Song Min. 李春涛, 宋敏. (2010). Innovation Activities of Chinese Manufacturing Enterprises: The Role of Ownership and CEO Incentives 中国制造业企业的 创新活动: 所有制和 CEO 激励的作用. Economic Research, 5.

Li Yingzhao, \& Wu Jihui. 李映照, 吴济慧. (2013). Research on the Relationship between Institutional Investors and R \& D Investment 机构投资者与 R \& D 投入关系研究. Science and Technology Management Research, 23.

Liu Xiaoyuan, \& Li Yongzhuang. 刘小元, 李永壮. (2012). Research and Development Intensity of Entrepreneurial Firms under the Influence of Board of Directors, Resource Constraints and Innovation Environment 董事会、资源约束与创新环境影响下的创 业企业研发强度. Soft Science, 6.

Luo Zhengying, Tang Lingling, \& Chang E. 罗正英, 汤玲玲, 常嫦. (2013). The Executive Team of Human Capital, Incentive Mechanism and Corporate R \& D Investment 高管团队人力资本、激励机制与企业研发投入. Journal of Soochow University, 3.

Tang Qingquan, \& Xie Weimin. 唐清泉, 解维敏. (2013). Executive Stock Ownership and Enterprise Innovation: Empirical Evidence from Chinese Listed Companies 高管 持股与企业创新一来自中国上市公司的经验证据. Modern Management Science, 3, 6-8.

Wen Fang. 文芳. (2008). Ownership Concentration, Equity Balance and Corporate R \& D Investment: Empirical Evidence from Listed Companies in China 股权集中度、股权 制衡与公司 R \& D 投资一来自中国上市公司的经验证据. Southern Economy, 4.

Zhao Yuehong, \& Xu Min. 赵月红, 许敏. (2013). RD Investment Impact on Corporate Performance-Based on 2006 Listed Companies in Yangtze River Delta-Panel Data of 2010 R \& D 投入对企业绩效影响的研究一基于长三角上市公司 2006-2010 年的面板 数据. Study on the Management of Science and Technology, 12. 
Submit or recommend next manuscript to SCIRP and we will provide best service for you:

Accepting pre-submission inquiries through Email, Facebook, LinkedIn, Twitter, etc. A wide selection of journals (inclusive of 9 subjects, more than 200 journals)

Providing 24-hour high-quality service

User-friendly online submission system

Fair and swift peer-review system

Efficient typesetting and proofreading procedure

Display of the result of downloads and visits, as well as the number of cited articles Maximum dissemination of your research work

Submit your manuscript at: http://papersubmission.scirp.org/

Or contact chnstd@scirp.org 